\title{
PERSONAGE AS AN INDEPENDENT OBJECT OF COPYRIGHT
}

\section{Zanina T. A., Kopytko A. P.}

The paper deals with the problematic issues regarding provision of legal protection of personages, as the question about the separate protection occurs when a personage is separated from the source, so that it conducts a new and independent life in individual works and is able to be memorized because it permanently remains in the imagination of readers and consumers after the original story is forgotten. The definition of the notion "personage», classification of personages is considered. Special conditions for granting legal protection to personages are defined. The international practice of detailing personage features of the work by means of which one determines whether contradictory personage is vested with features which allow to relate him to the protected objects of copyright is analyzed. An examples of judicial decisions in other countries, on the basis of which there are formulated more stringent criteria for the providing protection to personages, by means of which the courts could determine with greater certainty whether a controversial personage is vested with criteria which allow to attribute him to the protected objects of copyright are presented. The paper presents three main ways to protect the rights to the personage. The first is that a part of the work which can be used independently, is regarded as a work, and is protected by the Law of Ukraine "On Copyright and Related Rights». The second way is to protect the rights to the personage as an object of industrial property rights using the Law of Ukraine «On Protection of Rights to Marks for Goods and Services». The third way is realized by means of the Law of Ukraine "On protection from unfair competition». A brief description of these methods of protection are presented.

Keywords: literary work, personage, part of the work, object of copyright.

УДК $34.037: 347.77$

H. В. Кісіль, начальник відділу Державного підприємства «Інформаційні судові системи» Державної судової адміністрації України, кандидат сільськогосподарських наук, старший науковий співробітник

\section{ЗАГАЛЬНІ МЕТОДИЧНІ ПІДХОДИ ДО ПРОВЕДЕННЯ ЕКСПЕРТНИХ ДОСЛІДЖЕНЬ, ОБ’ЕКТАМИ ЯКИХ Є РІЗНІ ЗАСОБИ ІНДИВІДУАЛІЗАЦІї}

На основі узагальнення публікацій із теоретичних, загальнометодичних питань та проведеного аналізу судово-експертної практики у сфері інтелектуальної власності, де об 'сктами досліджень виступали засоби індивідуалізації учасників циивільного обороту, їх товарів і послуг, сформульовано методичні підходи до проведення експертних досліджень, пов'язаних із різними засобами індивідуалізації.

Ключові слова: судова експертиза, інтелектуальна власність, комерційні (фірмові) найменування, торговельні марки, зазначення походження mовару.

(C) Кісіль Н. В., 2016 
У загальній системі об'єктів права інтелектуальної власності серед видів інтелектуальної, творчої діяльності виділяється окрема група, до якої відносять засоби індивідуалізації учасників цивільного обороту, їх товарів i послуг ${ }^{1}$. Відповідно до законодавства України до зазначених засобів індивідуалізації належать такі об'єкти права інтелектуальної власності, як комерційні (фірмові) найменування, торговельні марки (знаки для товарів і послуг), зазначення походження товару. Спільною ознакою, що поєднує ці об’єкти та водночас відрізняє їх від інших об'єктів права інтелектуальної власності, $\epsilon$ їх призначення. Так, торговельні марки (знаки для товарів і послуг) та зазначення походження товарів $є$ позначеннями, які вирізняють споріднені товари й послуги певних учасників цивільного обороту, а комерційні найменування слугують засобом ідентифікації суб'єктів підприємницької діяльності та вказують на комерційне походження товарів і послуг.

Правова охорона надається таким засобам індивідуалізації учасників цивільного обороту, їх товарів і послуг: позначенням, які набули правової охорони в Україні як знак для товарів і послуг; позначенням (знакам) визнаним добре відомими в установленому законом порядку; комерційним (фірмовим) найменуванням; кваліфікованим зазначенням походження товарів. Як відомо, об'єкти права інтелектуальної власності за своєю природою належать до нематеріальних об'єктів, які набувають правової охорони лише за умови їх втілення в певний матеріальний об'єкт і дотримання всіх установлених законодавством умов. Так, право власності на знак для товарів і послуг засвідчується свідоцтвом із наведеними в ньому копією зображення знака та переліком товарів і послуг, що внесений до Державного реєстру свідоцтв України на знаки для товарів і послуг. Право на використання кваліфікованого зазначення походження товару засвідчується Свідоцтвом про реєстрацію права на використання кваліфікованого зазначення походження товару. Охорона прав на добре відомий знак здійснюється на підставі визнання знака добре відомим Апеляційною палатою - колегіальним органом Установи, що $є$ центральним органом виконавчої влади, яка реалізує державну політику у сфері інтелектуальної власності або судом. Правова охорона комерційних найменувань пов'язується із використанням такого найменування в процесі виготовлення, збуту товарів і послуг та надається лише тим найменуванням, які здатні вирізнити одну особу з-поміж інших і не вводять в оману споживачів щодо справжньої ії діяльності.

Як показує експертна практика, у цивільному обороті виникають конфлікти як між позначеннями, що отримали охорону як комерційні (фірмові) найменування, торговельні марки (знаки для товарів і послуг), кваліфіковані зазначення походження товару, так і між зазначеними засобами індиві-

1 Див.: Цивільний кодекс України : наук.-практ. комент. (пояснення, тлумачення, реком. $з$ використ. позицій вищ. суд. інстанцій, М-ва юстиції, наук., фахівців) : Т. 6: Право інтелектуальної власності / за ред. І. В. Спасибо-Фатєєвої. - Х. : ФО-П Лисяк Л. С., 2011. - 592 с. — (Коментарі та аналітика); Право інтелектуальної власності. Академічний курс : підручник для студ. вищ. навч. закл. / за ред. О. А. Підопригори, О. Д. Святоцького. - [2-ге вид., переробл. та допов.]. — К. : Вид. Дім «Ін Юре», 2004. $-672 \mathrm{c}$. 
дуалізації та позначеннями, що не набули правової охорони. При розгляді справ, пов'язаних зі встановленням порушення прав інтелектуальної власності на різні засоби індивідуалізації та справах щодо визнання недійсними реєстрацій на ці об'єкти, виникає необхідність у проведенні судової експертизи з метою встановлення факту тотожності або схожості різних засобів індивідуалізації та виявлення існування ймовірності введення в оману споживача щодо товару, послуги або особи. Необхідність вирішення цих експертних завдань пов'язана $з$ тим, що згідно із Законом ${ }^{1}$ не можуть одержати правову охорону позначення, які є оманливими або такими, що можуть увести в оману щодо товару, послуги або особи, яка виробляє товар або надає послугу.

Питанням розроблення методичних основ проведення експертних досліджень, пов'язаних із засобами індивідуалізації, присвячені праці ряду авторів $^{2}$. У цих роботах розкрито загальні підходи до проведення досліджень, пов'язаних із зазначеними об'єктами права інтелектуальної власності. Однак вивчення експертної практики показало, що існує необхідність у виявленні основних завдань експертизи, об'єктами якої виступають різні засоби індивідуалізації товарів і послуг, формулюванні переліку матеріалів, що необхідні для проведення повного та об'єктивного дослідження, а також уточненні алгоритмів проведення досліджень. Наведені результати є складовою частиною досліджень, проведених у 2013-2015 рр. згідно з Тематичним планом НДР науково-дослідних установ судових експертиз Міністерства юстиції України з метою розроблення методики проведення експертних досліджень, пов'язаних із засобами індивідуалізації. У результаті проведеного дослідження виявлено, що основними завданнями експертизи, об'єктом якої є різні засоби індивідуалізації, є:

- установлення тотожності різних засобів індивідуалізації або схожості настільки, що їх можна сплутати;

— установлення можливості введення в оману споживача щодо товару, послуги або особи.

Об'єктами експертизи при цьому можуть бути: знаки для товарів і послуг; кваліфіковані зазначення походження товару; комерційні (фірмові) найменування; позначення товарів і послуг, що не набули правової охорони.

Для забезпечення проведення повного дослідження та надання об'єктивного й обгрунтованого висновку експерту у сфері інтелектуальної власності мають бути надані об'єкти, у яких утілено об'єкт права інтелектуальної власності, а також інші матеріали, що містять відомості про об'єкти дослідження. Наприклад, копія свідоцтва на знак для товарів і послуг,

1 Див.: Про охорону прав на знаки для товарів і послуг : Закон України від 15 груд. 1993 р. № 3689-ХІІ // Відом. Верхов. Ради України. - 1994. — № 7. - Ст. 36.

2 Див.: Крайнєв П. П. Судові експертизи у сфері інтелектуальної власності / П. П. Крайнєв, Н. М. Ковальова, М. В. Мельников ; за ред. П. П. Крайнєва. - Вінниця : Поліграф. центр «Фенікс», ДІВП ВАТ «Інфракон»- «Інфракон-I», 2008. 376 с.; Методологічні основи судової експертизи об'єктів інтелектуальної власності : звіт про НДР (закл.) / МЮУ, КНДІСЕ, ХНДІСЕ ; кер Г. В. Прохоров-Лукін ; викон.: А. В. Андрєєва [та ін.]. — № ДР 0104U003403. — К. : КНДІСЕ, 2006. — 290 с. 
у якому наведене чітке зображення знака та перелік товарів і послуг, стосовно яких надається правова охорона; копія свідоцтва про реєстрацію права на використання кваліфікованого зазначення походження товару, у якому наведено кваліфіковане зазначення походження товару; актуальна виписка з Державного реєстру свідоцтв України на знаки для товарів і послуг, актуальний витяг з Державного реєстру назв місць походження та географічних зазначень походження товарів і прав на використання зареєстрованих кваліфікованих зазначень походження товарів; копія рішення Апеляційної палати Державної служби інтелектуальної власності України про визнання знака добре відомим в Україні, копія рішення суду про визнання знака добре відомим в Україні.

Матеріали, що надаються для проведення дослідження, пов'язаного із комерційними найменуваннями, повинні включати документи, які засвідчують дату першого використання (або найбільш ранню дату використання), відомості про товари і послуги, які пропонуються із застосуванням такого комерційного найменування, територіальні межі використання комерційного найменування тощо. При цьому треба зауважити, що реєстраційні та установчі документи юридичної особи не свідчать про фактичне використання комерційного найменування, яким $є$ укладення угод, проведення фінансових операцій, розміщення реклами в ЗМI, фактичне виробництво та/ або продаж товарів і послуг тощо. При цьому слід звернути увагу, що об'єктом експертного дослідження виступають саме знак для товарів і послуг, комерційні найменування; кваліфіковані зазначення походження товарів, що матеріалізовано в носіях, у яких ці об’єкти втілено.

Дослідження різних засобів індивідуалізації, що використовуються для індивідуалізації товарів, послуг і учасників цивільного обороту проводиться за стадіями експертного дослідження, які використовуються й в інших видах експертиз, а саме: підготовча стадія (попереднє дослідження), роздільне (аналітичне) дослідження, порівняльне дослідження, оцінювання результатів проведеного дослідження й формулювання висновків, оформлення ходу та результатів експертного дослідження висновком.

На підготовчій стадії експерт визначає:

- відповідність наданих матеріалів зазначеним в ухвалі (постанові) та/ чи в супровідному листі;

- достатність наданих матеріалів для вирішення поставлених перед експертом завдань;

- наявність усіх аркушів у матеріалах справи та правильність їх нумерації (якщо надані на дослідження матеріали не пронумеровані й не прошиті, то це робить комісія експертів, про що складається відповідний акт);

- наявність достатніх відомостей про об'єкти дослідження (знаки для товарів і послуг, комерційні (фірмові) найменування, кваліфіковані зазначення походження товарів) та об'єктів, що протиставляються.

Після попереднього ознайомлення з матеріалами справи з'ясовується, чи зрозумілий експерту зміст експертного завдання, поставленого органом (особою), що призначив експертизу (залучив експерта), та чи входить його вирішення до компетенції експерта. 
Проводиться ідентифікація об’єктів, що підлягають дослідженню, та встановлюється перелік товарів і послуг, для яких засоби індивідуалізації зареєстровані або використовуються. Якщо об'єкт та/або перелік товарів і послуг не визначений в ухвалі суду, експерт зобов'язаний подати клопотання до суду про уточнення змісту завдання й/або визначення об'єктів дослідження. Якщо об’єктом дослідження виступають знаки, які визнані добре відомими, при цьому матеріали справи не містять зображення такого знака та/або перелік товарів і послуг, для яких він визнаний добре відомим, а також не зазначено дату, на яку знак визнаний добре відомим в Україні, експерт зобов'язаний подати клопотання до суду про уточнення змісту завдання та/або визначення об'єктів дослідження.

На цій стадії також розглядається доцільність вирішення експертом питань у порядку експертної ініціативи та необхідність залучення до проведення експертизи фахівців, які володіють певними спеціальними знаннями у відповідній галузі науки, техніки або ремесла, що необхідні для проведення повного та об'єктивного дослідження. За потреби використання в тексті дослідження зображень об'єктів, здійснюється фотозйомка або проводиться фіксація іншим технічним засобом. За відсутності певних матеріалів, необхідних для проведення експертизи, або наявності неякісних зображень і нечитабельних текстів, експертом подається клопотання про надання додаткових матеріалів особі або органу, що призначив експертизу.

На стадії роздільного (аналітичного) дослідження експерт описує об'єкти, що підлягають дослідженню, виявляє й аналізує їх властивості та ознаки. При цьому відображаються однорідні властивості та ознаки досліджуваних об'єктів, які виділяються за результатом вивчення всіх відомостей, що містяться в матеріалах справи. Якщо на цьому етапі буде встановлено, що подані на дослідження матеріальні носії (наприклад, фотознімки, ксерокопії документів тощо) неповно або неточно відтворюють об'єкти дослідження та порівняльні зразки, або наданих матеріалів недостатньо для вирішення поставленого завдання, то експертом в установленому порядку направляється клопотання про надання додаткових матеріалів.

Експерт виявляє, з яких видів позначень складаються об'єкти, що підлягають дослідженню, а саме: чи містять вони ознаки словесних, зображувальних, об'ємних, комбінованих або інших позначень і визначає елементи, які в них домінують. Серед елементів, з яких складаються досліджувані позначення, що використовуються для індивідуалізації товарів, послуг та учасників цивільного обороту, виділяються елементи, які законодавством виключаються із правової охорони. Ці позначення можуть входити до складу знака для товарів і послуг як елементи, що не охороняються, якщо вони не займають у позначенні домінуючого положення. При цьому береться до уваги смислове та/або просторове значення такого елемента.

При дослідженні знака для товарів $і$ послуг у висновку наводиться зображення знака для товарів і послуг, зазначається перелік товарів і послуг, для яких знак зареєстровано та щодо яких діє охорона, відомості про кольори, яким надана охорона, дата подання заявки, номер заявки, якщо є пріоритет - дата пріоритету, відомості про заявника, відомості про власника, 
дата публікації про видачу свідоцтва та внесення відомостей до реєстру, номер бюлетеня, визначається, до якого виду позначення належить зображення (словесне, зображувальне, комбіноване тощо), визначають домінуючі та другорядні елементи позначення.

При дослідженні кваліфікованого зазначення походження товарів у висновку наводиться зображення такого зазначення, номер заявки, дата реєстрації та/або скасування рішення про реєстрацію, дата публікації відомостей, товари і послуги, для яких воно зареєстроване, коло осіб, що мають право його використовувати, зазначаються межі території, на якій його зареєстровано, визначається, до якого виду позначення належить зображення (словесне, зображувальне, комбіноване тощо), визначають домінуючі та другорядні елементи позначення (для цього використовується актуальна виписка із Державного реєстру України назв місць походження товарів і прав на використання зареєстрованих кваліфікованих зазначень походження товарів).

При проведенні дослідження комериійного (фірмового) найменування у висновку наводиться інформація про комерційне (фірмове) найменування, відомості про фактичне перше використання (або найбільш ранню дату використання), відомості про фактичні види діяльності, відомості про територію діяльності, визначається основна (корпус) і вирізняльна частини (обов'язкова та факультативна) комерційного найменування.

Під час дослідження позначень, які не отримали правової охорони, у висновку надається зображення позначення, відомості про товари і послуги, для яких застосовується позначення, особу, що використовує позначення, за необхідності: дата, з якої воно стало відоме, та територія, на якій використовується позначення, визначається, до якого виду позначення належить зображення (словесне, зображувальне, комбіноване тощо), визначають домінуючі та другорядні його елементи.

Результати аналітичного дослідження із наведенням відповідних ілюстрацій відображаються в дослідницькій частині висновку.

На стадії порівняльного дослідження проводиться зіставлення схожих загальних і окремих ознак різних засобів індивідуалізації, аналізуються наявні збіги та розбіжності й проводиться формування проміжного висновку про наявність чи відсутність тотожності (схожості) відповідних засобів індивідуалізації або про можливість уведення в оману. Ця стадія завжди має місце під час установлення тотожності та схожості різних засобів індивідуалізації настільки, що їх можна сплутати, або встановлення можливості введення в оману споживача щодо товару, послуги або особи.

У загальному вигляді порівняльне дослідження проводиться за двома етапами. На першому етапі встановлюється спорідненість товарів або товарів і послуг, або послуг і послуг. На другому етапі здійснюється зіставлення загальних та окремих ознак різних засобів індивідуалізації. При цьому слід зазначити, що послідовність першого та другого етапів дослідження може замінюватися залежно від поставленого експертного завдання. Послідовність його вирішення вирішального значення не має. 
Установлення схожості грунтується на комплексному, усебічному аналізі порівнюваних позначень, а саме: сприйнятті домінуючих і другорядних графічних елементів, зіставленні звукового складу, асоціативного ряду, ступеня семантичної близькості. При цьому головним є перше зорове сприйняття досліджуваних позначень. Саме перше зорове сприйняття будь-якого об'єкта має вплив на свідомість людини, аналогічним чином у свідомості споживача запам'ятовується й позначення. Під час дослідження схожості комбінованих позначень визначається схожість як усього позначення в цілому, так і його складових елементів, з урахуванням значущості розташування тотожного чи схожого елемента в заявленому позначенні. Компоненти, які мають незначну розрізнювальну здатність, до уваги не беруться, а порівнянню підлягають домінуючі елементи позначень. Хід проведення досліджень за цим етапом залежить від виду позначень, що входять до складу порівнювальних засобів індивідуалізації.

Оскільки комерційні (фірмові) найменування та кваліфіковані зазначення походження товарів за своєю природою в переважній більшості $\epsilon$ словесними позначеннями (окремі винятки становлять географічні зазначення, до складу яких можуть входити зображувальні елементи), порівняльне дослідження знаків для товарів і послуг (словесних) і комерційних найменувань, знаків для товарів і послуг та зазначень походження товарів, комерційних найменувань і зазначень походження товарів проводиться відповідно до методичних підходів, передбачених для дослідження словесних позначень.

Дослідження таких об’ єктів, як знак для товарів і послуг та позначення, що не набуло правової охорони; знак для товарів і послуг та добре відомий знак, що містять зображувальні, об'ємні або комбіновані елементи, проводиться враховуючи підходи, передбачені для дослідження цих видів.

Результати порівняльного дослідження з визначення спорідненості із наведенням відповідних обгрунтувань відображаються в дослідницькій частині висновку, та робиться проміжний висновок про спорідненість або неспорідненість досліджуваних товарів і послуг. Після чого формується проміжний висновок про наявність чи відсутність тотожності (схожості) відповідних засобів індивідуалізації, або щодо введення в оману споживача стосовно товару, послуги виробника тощо.

Основні підходи до виявлення тотожності або схожості позначень на такі, що їх можна сплутати, а також визначення спорідненості товарів і послуг при проведенні судової експертизи розглянуто в працях П. П. Крайнєва, Г. В. Прохорова-Лукіна та інших авторів ${ }^{1}$.

${ }^{1}$ Див.: Крайнєв П. П., Ковальова Н. М., Мельников М. В. Указ. праця; Методика судово-експертного дослідження зазначень походження товарів : звіт про НДР (закл.) / МЮ України, КНДІСЕ ; кер. Г. В. Прохоров-Лукін ; викон.: А. В. Андрєєва [та ін.]. № ДР 0111U000411. - К., 2011. - 114 с.; Методика судово-експертного дослідження знаків для товарів і послуг (торговельних марок) : звіт про НДР (закл.) / МЮ України, КНДІСЕ, НДЦСЕПІВ, НДІІВ АпрНУ ; кер. Г. В. Прохоров-Лукін ; викон.: А. В. Андрєєва [та ін.]. — № ДР 0108U005823. — К. : КНДІСЕ, 2009. — 400 с.; 
На основі узагальнення літературних джерел і чинних нормативних актів нами сформульовано алгоритми вирішення експертних завдань щодо різних засобів індивідуалізації, які викладені в Методиці проведення експертних досліджень, пов'язаних із засобами індивідуалізації'. В основу запропонованих методичних рекомендацій покладено підходи визначення схожості засобів індивідуалізації, викладені в Правилах складання, подання та розгляду заявки на видачу свідоцтва України на знак для товарів і послуг, Методичних рекомендаціях з окремих питань проведення експертизи заявки на знак для товарів і послуг, регламентах проведення експертизи в процесі набуття прав на торговельні марки в Європейському Союзі, Великій Британії, Сполучених Штатах Америки, Франції, Російській Федерації, Республіці Білорусь.

Після проведення порівняльного дослідження оичінюються результати дослідження та формулюються висновки. На цій стадії оцінюється вся сукупність виявлених у результаті порівняльного дослідження збігів і розбіжностей у досліджуваних об'єктах, ураховуючи результати проведення дослідження на спорідненість товарів і послуг. У разі розбіжності проміжних висновків визначається, які з ознак найбільш важливі (вагомі) для конкретного позначення. Проводиться зіставлення з іншими матеріалами справи, поясненнями, наданими сторонами та додатково залученими фахівцями, після чого формулюється заключний висновок про наявність чи відсутність тотожності (схожості) відповідних засобів індивідуалізації, або щодо введення в оману споживача стосовно товару, послуги, виробника.

На заключній стадіï експертного дослідження його результати оформлюються у висновку судового експерта відповідно до встановлених правил (згідно із процесуальним законодавством та Інструкцією про призначення та проведення судових експертиз та експертних досліджень).

Отже, на основі узагальнення публікацій із теоретичних, загально-методичних питань і проведеного аналізу судово-експертної практики у сфері інтелектуальної власності щодо різних засобів індивідуалізації учасників цивільного обороту, їх товарів і послуг сформульовано методичні підходи до проведення експертних досліджень, пов'язаних із засобами індивідуалізації. Проте слід зазначити, що у зв'язку з накопиченням досвіду з експертної практики певні положення можуть потребувати уточнення й розширення, то в цьому разі до Методичних рекомендацій будуть уноситися відповідні зміни.

Методика судової експертизи комерційних (фірмових) найменувань : звіт про НДР (закл.) / МЮ України, КНДІСЕ ; кер. Г. В. Прохоров-Лукін ; викон.: А. В. Андрєєва [та ін.]. — № ДР 0110U002834. - К., 2011. — 78 с.

Див.: Методика проведення експертних досліджень, пов'язаних із засобами індивідуалізації : звіт НДР (закл.) / МЮ України, НДЦСЕПІВ ; кер. І. В. Стародубов ; викон.: Н. В. Кісіль [та ін.]. — № ДР 0113U000471. — К. : НДЦСЕПІВ, 2015. — 99 с. 


\title{
ОБЩИЕ МЕТОДИЧЕСКИЕ ПОДХОДЫ К ПРОВЕДЕНИЮ ЭКСПЕРТНЫХ ИССЛЕДОВАНИЙ, ОБЫЕКТАМИ КОТОРЫХ ЯВЛЯЮТСЯ РАЗЛИЧНЫЕ СРЕДСТВА ИНДИВИДУАЛИЗАЦИИ
}

\author{
Кисиль Н. В.
}

На основе обобщения публикаций по теоретическим, общеметодическим вопросам и проведенного анализа судебно-экспертной практики в сфере интеллектуальной собственности, объектами исследований которых выступали средства индивидуализации участников гражданского оборота, их товаров и услуг, сформулированы методические подходы к проведению экспертных исследований, связанных с различными средствами индивидуализачии.

Ключевые слова: судебная экспертиза, интеллектуальная собственность, коммерческие (фирменные) наименования, торговые марки, обозначения происхождения товара.

\section{GENERAL METHODICAL APPROACHES TO CARRY OUT EXPERT RESEARCHES WHOSE OBJECTS ARE VARIOUS MEANS OF INDIVIDUALIZATION}

\section{Kisil N. $\boldsymbol{V}$.}

When considering the cases related to the establishment of intellectual property rights infringement on the various means of individualization and the cases on the invalidation of registrations for these objects, there arises a need in carrying out forensic examination in the area of intellectual property. The main objectives of the examination whose objects are various means of individualization of civil turnover participants, their goods and services are: establishment of the identity of the various means of individualization or the similarity to the confusion extent, as well establishing the probability of consumer mislead regarding the product, service or person. The objects of the examination in the field of intellectual property may be: trademarks, qualified designation of the goods origin, commercial (firm) names; notation of the goods and services that don thave legal protection. Since the commercial (firm) name and the qualified indication of the goods origin by their nature are overwhelmingly verbal designations, a comparative study of the trademarks for goods and services (verbal), and commercial names, trademarks for goods and services and designations of the goods origin, commercial names and designations of the goods origin are carried out in accordance with the methodical approaches provided for the study of verbal designations. The study of such objects as trademarks for goods and services and the notation which did not receive a legal protection; marks for goods and services, and well-known marks that contain figurative, volumetric or combined elements are carried out taking into account the approaches foreseen for the study of these types. Expert research is conducted according to the following stages: the preparation stage (preliminary study), separate (analytical) study, comparative study, evaluation of the carried out research results and formulation of conclusions, execution of the progress and results of the expert examination.

Keywords: forensic examination, intellectual property, commercial (firm) names, trademarks, notation of the goods origin. 